Molly Kottemann · Adrienne Kish · Chika Iloanusi

Sarah Bjork · Jocelyne DiRuggiero

\title{
Physiological responses of the halophilic archaeon Halobacterium sp. strain NRC1 to desiccation and gamma irradiation
}

Received: 16 November 2004 / Accepted: 28 January 2005/Published online: 21 April 2005

(C) Springer-Verlag 2005

\begin{abstract}
We report that the halophilic archaeon Halobacterium sp. strain NRC-1 is highly resistant to desiccation, high vacuum and ${ }^{60} \mathrm{Co}$ gamma irradiation. Halobacterium sp. was able to repair extensive double strand DNA breaks (DSBs) in its genomic DNA, produced both by desiccation and by gamma irradiation, within hours of damage induction. We propose that resistance to high vacuum and ${ }^{60} \mathrm{Co}$ gamma irradiation is a consequence of its adaptation to desiccating conditions. Gamma resistance in Halobacterium sp. was dependent on growth stage with cultures in earlier stages exhibiting higher resistance. Membrane pigments, specifically bacterioruberin, offered protection against cellular damages induced by high doses ( $5 \mathrm{kGy}$ ) of gamma irradiation. High-salt conditions were found to create a protective environment against gamma irradiation in vivo by comparing the amount of DSBs induced by ionizing radiation in the chromosomal DNA of Halobacterium $\mathrm{sp}$. to that of the more radiation-sensitive Escherichia coli that grows in lower-salt conditions. No inducible response was observed after exposing Halobacterium sp. to a nonlethal dose $(0.5 \mathrm{kGy})$ of gamma ray and subsequently exposing the cells to either a high dose $(5 \mathrm{kGy})$ of gamma ray or desiccating conditions. We find that the hypersaline environment in which Halobacterium sp. flourishes is a fundamental factor for its resistance to desiccation, damaging radiation and high vacuum.
\end{abstract}

Communicated by W.D. Grant

M. Kottemann · A. Kish · C. Iloanusi - S. Bjork

J. DiRuggiero $(\square)$

Department of Cell Biology and Molecular Genetics,

University of Maryland, 3221 H.J. Patterson Hall,

College Park, MD, 20742, USA

E-mail: JD92@umail.umd.edu

Tel.: + 1-301-4054598

Fax: + 1-301-3149081

J. DiRuggiero

Center of Marine Biotechnology,

University of Maryland Biotechnology Institute,

Baltimore, MD, USA
Keywords Halophiles Ionizing radiation

Desiccation - Double-strand breaks - DNA repair

Abbreviations DSBs: Double-strand breaks .

ROS: Reactive oxygen species - EMS: Ethyl

methanesulfonate $\cdot$ Gy: Gray

\section{Introduction}

Hypersaline environments are characterized by extremely high ionic strength, up to ten times the salinity of seawater, by elevated temperatures and by high levels of UV radiation. These conditions lead to periodic evaporation of water resulting in concentration of salts, exposure of cells to desiccation and DNA damage (Potts 1994; Martin et al. 2000). UV radiation promotes the formation of two types of photoproducts; (6-4) photoproducts and cyclobutane pyrimidine dimers. In the halophilic archaeon Halobacterium sp. strain NRC-1, the majority of lesions are cyclobutane pyrimidine dimers: these lesions are removed via photoreactivation using a photolyase encoded by the $p h r 2$ gene (McCready 1996; Baliga et al. 2004). Stress response to intense UV exposure in Halobacterium sp. include a down-regulation of all genes involved in the production of gas vesicles, causing the cells to sink in the water column therefore avoiding the deleterious effects of UV irradiation (Baliga et al. 2004).

Induction of DNA double-stranded breaks (DSBs) in microorganisms has been observed under both desiccating conditions and gamma irradiation (DiRuggiero et al. 1999; Mattimore and Battista 1996). The mechanism for DSB formation after exposure to desiccation is poorly understood. In contrast, ionizing radiation is a well-characterized exogenous source of free radicals produced via the radiolysis of water, which account for more than $80 \%$ of the DNA damage, whereas less than $20 \%$ is the result of direct effects of $\gamma$-photons (Riley 1994). Reactive oxygen species (ROS) are able to modify 
DNA bases into such forms as the well-characterized 8hydroxy-2'-deoxyguanosine resulting in mismatches, apurinic/abasic sites and strand breaks (Riley 1994). These damages often occur in clusters within two helical turns of the DNA on opposite strands resulting in the formation of DSBs during attempted base excision repair (Blaisdell and Wallace 2001; Dianov et al. 2001). Furthermore, hydrogen peroxide $\left(\mathrm{H}_{2} \mathrm{O}_{2}\right)$ can react with $\mathrm{Fe}^{2+}$, by the Fenton reaction, to produce the highly reactive hydroxyl radical that is able to attack and damage proteins, lipids and nucleic acids. Scavenging of ROS is the function of superoxide dismutase, catalase and peroxidase that aid in preventing cellular damages by ROS (Salin and Brown-Peterson 1993). Low intracellular concentrations of $\mathrm{Fe}^{2+}$ combine with high concentrations of $\mathrm{Mn}^{2+}$ have been identified as factors that limit the formation of hydroxyl radicals in Deinococcus radiodurans from $\mathrm{H}_{2} \mathrm{O}_{2}$ via the Fenton reaction (Daly et al. 2004).

Mechanisms for the maintenance of genome fidelity under extremely DNA damaging conditions are especially vital for the survival of life in hypersaline environments. Adaptations, for survival of desiccation, of many prokaryotes include sporulation (Nicholson et al. 2000) and the production of extracellular polysaccharides (Potts 1994), neither of which is utilized by Halobacterium sp. Instead, genome analysis showed that Halobacterium sp. contains putative genes for all major DNA repair pathways (nucleotide excision repair, base excision repair, photoreactivation, homologous recombination, translesion synthesis, and mismatch repair) found in both Bacteria and Eukarya ( $\mathrm{Ng}$ et al. 1997), suggesting a major role for DNA repair in Halobacterium sp. resistances to extreme conditions such as desiccation. Efficient DNA repair upon rehydration is essential for maintaining DNA fidelity in other desiccation-resistant species such as Chrococcidiopsis sp. and D. radiodurans (Billi et al. 2000; Battista et al. 1999). Adaptations to desiccation, and the resulting DSBs, have been hypothesized as the source of gamma radiation resistance in D. radiodurans (Mattimore and Battista 1996) as cells on the earth's surface are not naturally exposed to ionizing radiation. A similar mechanism likely results in the ability of Halobacterium sp. to withstand high levels of gamma irradiation. Additionally, protective mechanisms such as membrane pigments, including $\mathrm{C}_{50}$ carotenoid, bacterioruberin and intracellular $\mathrm{KCl}$ were found to be important in UV and gamma-ray protection in Halobacterium salinarium through the scavenging of hydroxyl radicals (Shahmohammadi et al. 1998).

In this work, we describe the effects of desiccation, high vacuum and gamma irradiation on the survival and recovery of Halobacterium $s p$. strain NRC-1. Halobacterium $s p$. is an excellent model organism for examining the cellular mechanisms involved in survival under damaging conditions and simulated space conditions (Mancinelli et al. 1998). It is an extremely halophilic archaeon that grows optimally under aerobic conditions in $4 \mathrm{M} \mathrm{NaCl}$ and maintains an internal salt concentration of $\mathrm{K}^{+}$and $\mathrm{Na}^{+}$to balance the extracellular salt concentration (Lanyi 1974; DasSarma 1995). Ease of culturing, a completed genome sequence ( $\mathrm{Ng}$ et al. 1997) and efficient genetic and biochemical systems have enabled detailed investigations of the molecular response of this halophile model to a range of environmental conditions (Baliga et al. 2004; Mancinelli et al. 1998). This could also be extended to Martian conditions where high concentrations of sodium chloride and bromine compounds were found by the Mars Exploration Rovers in the soils of Meridiani Planum resulting from the evaporation over time of water from a brine solution (Rieder et al. 2004). Halobacterium sp. inhabits a challenging environment for the maintenance of genomic stability. Adaptive mechanisms for stress induction were investigated along with the protective effects of pigments and salt in vivo.

\section{Materials and methods}

Microbial strains and growth conditions

Halobacterium sp. strain NRC-1 (ATCC number: 700922), Halobacterium sp. mutants BA3 [colorless random ethyl methanesulfonate (EMS) mutant] and $\Delta$ Pho81 [deletion mutation lacking bop (bacteriorhodopsin), sop-1 and sop-2 (sensory rhodopsins 1 and 2), and hop (halorhodopsin) prepared using the protocol by Peck et al. (2000); a gift from Nitin Baliga] and Escherichia coli K12 (ATCC number: 10798) were used in this study. Halobacterium sp. was grown in GN101 medium $\left[250 \mathrm{~g} / \mathrm{L} \mathrm{NaCl}, 20 \mathrm{~g} / \mathrm{L} \mathrm{MgSO}_{4}, 2 \mathrm{~g} / \mathrm{L} \mathrm{KCl}, 3 \mathrm{~g} /\right.$ L sodium citrate, $10 \mathrm{~g} / \mathrm{L}$ bacteriological peptone (Oxoid brand)] with the addition of $1 \mathrm{~mL} / \mathrm{L}$ trace elements solution $\left(31.5 \mathrm{mg} / \mathrm{L} \quad \mathrm{FeSO}_{4} .7 \mathrm{H}_{2} \mathrm{O}, 4.4 \mathrm{mg} / \mathrm{L} \quad \mathrm{ZnSO}_{4}\right.$. $7 \mathrm{H}_{2} \mathrm{O}, 3.3 \mathrm{mg} / \mathrm{L} \mathrm{MnSO}{ }_{4} \cdot \mathrm{H}_{2} \mathrm{O}, 0.1 \mathrm{mg} / \mathrm{L} \mathrm{CuSO}_{4} .5 \mathrm{H}_{2} \mathrm{O}$ ), at $42^{\circ} \mathrm{C}$ with shaking at $220 \mathrm{rpm}$ (Innova 4080, New Brunswick Scientific). The GN101 medium was supplemented with $50 \mu \mathrm{g} / \mathrm{L}$ uracil for strains derived from a $\Delta u r a 3$ background ( $\Delta$ Pho81), and with $20 \mathrm{~g} / \mathrm{L}$ Agar for solid medium. Basal salt solution (BSS) was used as a nonnutrient buffer during irradiation, and was composed of GN101 medium without peptone and trace elements. E. coli were cultured in Luria Broth (LB) and low salt medium [basal salt solution diluted $1 / 50$ with the addition of $10 \mathrm{~g} / \mathrm{L}$ oxoid brand peptone and trace elements solution $(1 \mathrm{~mL} / \mathrm{L})]$.

\section{EMS mutant construction}

Halobacterium sp. cells were incubated with $0.076 \mathrm{M}$ ethyl methanesulfonate (EMS) in basal salt solution at $37^{\circ} \mathrm{C}$ with shaking for $1 \mathrm{~h}(0.017 \%$ survival $)$ after which an equal volume of $10 \%(\mathrm{w} / \mathrm{v})$ sodium thiosulfate was added to the cell suspension. Cells were washed twice in BSS, recovered by centrifugation and 
resuspended in the same buffer. Aliquots were plated onto solid GN101 medium and incubated at $42^{\circ} \mathrm{C}$ for 7 days. Colonies were transferred onto solid GN101medium grid-marked plates and further incubated at $42^{\circ} \mathrm{C}$. 1,415 surviving colonies with varied colony size and appearance were selected for mutant screening including one colony exhibiting white pigmentation that was used in this study (BA3 mutant).

Exposure to desiccation and high vacuum

Halobacterium sp. cultures grown to an $\mathrm{OD}_{600 \mathrm{~nm}}$ of 0.8 (late $\log$ phase) were concentrated 20-fold in BSS, placed onto glass microscope cover slips $(2 \times 50 \mu \mathrm{l}$ per cover slip as 4-5 dots) and allowed to dry completely. Cover slips were placed in six-well plates with perforated lids and exposed to high vacuum $\left(10^{-6} \mathrm{~Pa}\right)$ using a high vacuum chamber at the NASA Goddard Space Flight Center (Greenbelt, MD, USA) for 2, 6, 10, 15, and 20 days (Saffary et al. 2002). For desiccation at ambient pressure, cover slips were placed in open glass Petri dishes with $36 \mathrm{~g}$ of Drierite desiccant $(97 \%$ $\mathrm{CaSO}_{4}$ and $3 \% \mathrm{CoCl}_{2}$ ) each, covered in tin foil and placed in a NAPCO model 5,831 vacuum oven at a pressure of $5 \mathrm{~mm} \mathrm{Hg}$ at RT for 12 days. Cells were rehydrated by placing cover slips in $5 \mathrm{~mL}$ of BSS with moderate agitation for $30 \mathrm{~min}$ at room temperature (RT). The resulting cell suspensions were concentrated by centrifugation at $5,000 \times g$, RT for $10 \mathrm{~min}$, resuspended in BSS and plated onto solid GN101 medium to quantify cell survival by colony counts, after 4 7 days of incubation at $42^{\circ} \mathrm{C}$. Control samples were processed in the same manner immediately after preparation and were not permitted to dry. For recovery experiments, cells were resuspended in GN101 medium following rehydration and incubated at $42^{\circ} \mathrm{C}$ with shaking. At time points $0,8,24$, and $28 \mathrm{~h}$ of incubation postprocessing, the cultures were centrifuged at $5,000 \times g, 4^{\circ} \mathrm{C}$, for $5 \mathrm{~min}$, the supernatant was decanted, and the cell pellets stored at $-20^{\circ} \mathrm{C}$ for subsequent DNA extraction as described below.

\section{Gamma irradiation}

All gamma-ray exposure experiments, unless otherwise stated, were conducted as follows: cultures of Halobacterium sp. grown to an $\mathrm{OD}_{600} \mathrm{~nm}$ of 0.8 at $42^{\circ} \mathrm{C}$ were centrifuged at $5,000 \times g$, at RT for $5 \mathrm{~min}$. Cells were resuspended in one volume of BSS and exposed to $2.5-7.5 \mathrm{kGy}$ of gamma-ray at $22^{\circ} \mathrm{C}$ (measured with an Omega Engineering Model HH 611PL4F Type K logging thermometer during irradiation) using a 26,000-curie $(9.6 \mathrm{E} 14 \mathrm{~Bq}){ }^{60} \mathrm{Co}$ source located at University of Maryland College Park Gamma Test Facility at a dose rate of $7.3 \mathrm{kGy} / \mathrm{min}$. Controls were kept at RT. Irradiated samples and controls were diluted in BSS and plated on GN101 solid medium.
Survival was quantified as described above. For analyses of chromosomal fragmentation repair, Halobacterium sp. were exposed to gamma-ray as described above, followed by incubation in $\mathrm{GN} 101$ at $42^{\circ} \mathrm{C}$ with shaking. Samples were removed for processing at 0,8 , 24 , and $48 \mathrm{~h}$. The control and $0 \mathrm{~h}$ samples were processed immediately after resuspension in GN101. Samples were centrifuged at $5,000 \times g, 4^{\circ} \mathrm{C}$, for $5 \mathrm{~min}$ and the pellets stored at $-20^{\circ} \mathrm{C}$ for subsequent DNA extraction as described below. E. coli cultures were processed in the same manner but using low salt medium for culture growth, irradiation and postirradiation incubation at $37^{\circ} \mathrm{C}$.

Acquired resistance in Halobacterium sp. was determined by first exposing the cells to $0.5 \mathrm{kGy}$ of gammaray in BSS, followed by $1 \mathrm{~h}$ incubation in GN101 at $42^{\circ} \mathrm{C}$ with shaking, and then either exposure to $5 \mathrm{kGy}$ or 12 days of desiccation as described above. Controls with and without preirradiation were processed in the same way. Survival was quantified by colony count as described above.

\section{DNA preparation}

DNA was prepared according to $\mathrm{Ng}$ et al. 1995, with the following modifications: frozen cell pellets were thawed on ice and resuspended in $1 / 20$ volume chilled BSS. Sterile water was added to $1 / 3$ volume to lyse cells and a crude extraction of DNA was performed using 25:24:1 phenol:chloroform:isoamyl alcohol, subsequent precipitation in $95 \%$ ethanol and resuspension into Tris-Low EDTA (TLE pH 8; $10 \mathrm{mM}$ Tris, $0.1 \mathrm{mM}$ EDTA). RNAse ONE (Promega) was added to a final concentration of 0.3 units $/ \mu 1$, and the mixture was incubated for $75 \mathrm{~min}$ at $37^{\circ} \mathrm{C}$ followed by phenol-chloroform extractions and ethanol precipitation as described above. DNA was visualized by $0.8 \%(\mathrm{w} / \mathrm{v})$ TAE agarose gel electrophoresis and ethidium bromide staining. Densitometry analysis was conducted using the ImageQuaNT5.0 software (Molecular Dynamics). Fluorescence intensity of $0 \mathrm{kGy}$ was used as background and subtracted from the fluorescence intensity for 2.5, 5 and $7.5 \mathrm{kGy}$ samples.

\section{Results and discussion}

Halobacterium sp. is highly resistant to desiccation, high vacuum, and ${ }^{60} \mathrm{Co}$ gamma-ray irradiation

The survival of Halobacterium sp. to desiccation at ambient pressure and high vacuum $\left(10^{-6} \mathrm{~Pa}\right)$ was evaluated for up to 20 days of exposure. Under these conditions, the medium formed large salt crystals in which the cells were encased (Fig. 1a, b). For both challenges, a slow decrease in survival was observed over time, with $25 \%$ of cells viable after 20 days (Fig. 2a). There was no significant difference in survival 

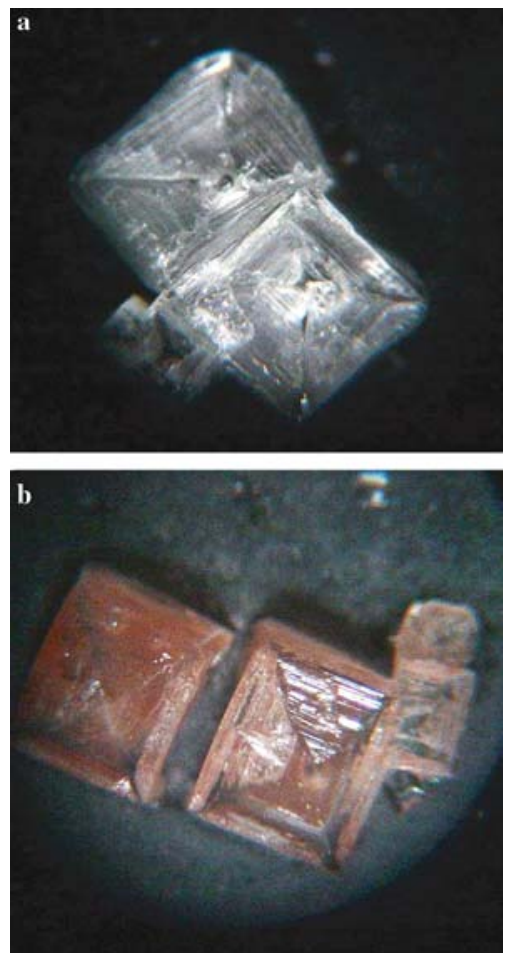

Fig. 1 Salt crystals from GN101 culture medium after 2 days of desiccation a un-inoculated and $\mathbf{b}$ inoculated with Halobacterium sp.

after exposure to either desiccation or high vacuum, suggesting that salt crystals themselves offer a level of cellular protection from environmental stresses. Indeed, viable halobacteria have been isolated from Triassic and Permian salt deposits (McGenity et al. 2000; Vreeland and Rosenzweig 2002), and more recently haloarchaeal 16S rDNA was detected in single-crystal and brine-inclusion-rich microsamples of ancient halite (Fish et al. 2002). The resistance of vegetative Halobacterium sp. cells is still less than that of Bacillus subtilis spores that were able to withstand exposure to $10^{-6} \mathrm{~Pa}$ at $77 \mathrm{~K}$ for $24 \mathrm{~h}$ with $75 \%$ survival, while Halobacterium halobium cells were completely killed (Koike et al. 1992; Nicholson et al. 2000).

Halobacterium sp. cells showed high resistance to ${ }^{60} \mathrm{Co}$ gamma-ray without distinct loss of viability up to $2.5 \mathrm{kGy}$ (Fig. 2b) and with a $\mathrm{D}_{10}$ of $5 \mathrm{kGy}$. This is higher than the $\mathrm{D}_{10}$ reported for Pyrococcus furiosus (DiRuggiero et al. 1997) of $3 \mathrm{kGy}$ and within the range reported for Thermococcus gammatolerans isolates with a $\mathrm{D}_{10}$ of 4-6 kGy (Jolivet et al. 2003, 2004). At the extremes of gamma sensitivity/resistance, E. coli has a $\mathrm{D}_{10}$ value of $0.25 \mathrm{kGy}$ (Clavero et al. 1994) whereas D. radiodurans $\mathrm{D}_{10}$ is $10 \mathrm{kGy}$ (van Gerwen et al. 1999). Halobacterium salinarium was reported to have a tenfold lower tolerance for gamma irradiation than our strain of Halobacterium (Shahmohammadi et al. 1998), which is in contrast with the reported rates of UV survival that were identical between the two strains (Baliga et al. 2004; Shahmohammadi et al. 1998). This
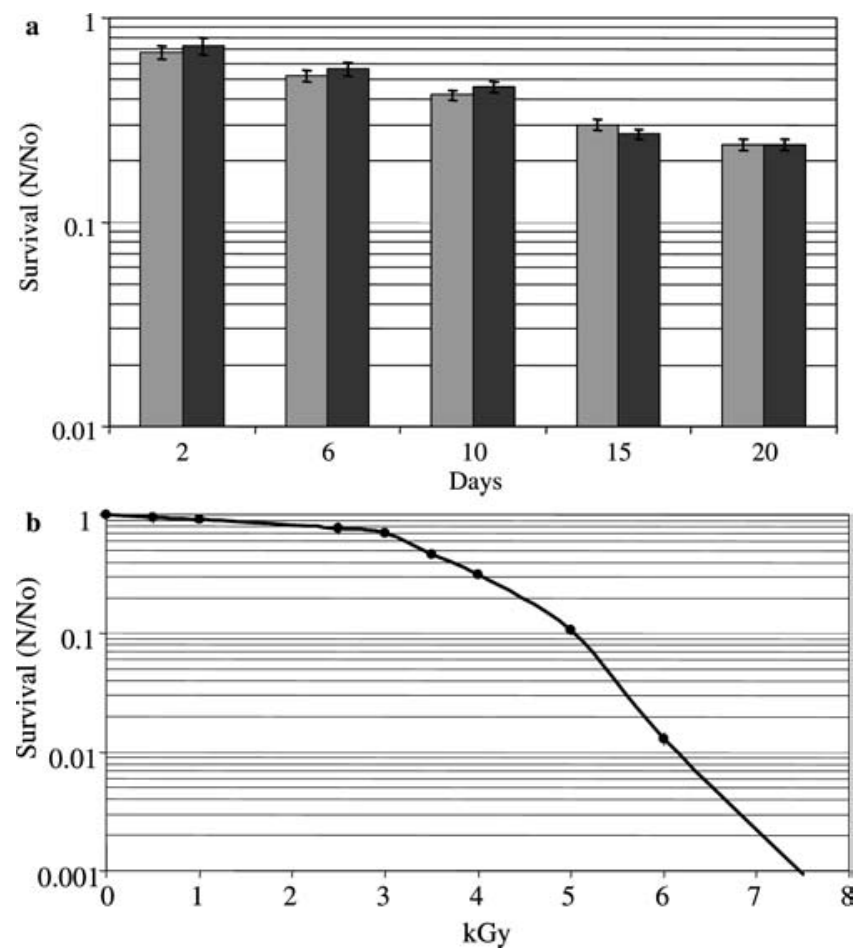

Fig. 2 Halobacterium sp. survival following a desiccation (dark bars) and high vacuum (light bars); b ${ }^{60} \mathrm{Co}$ gamma irradiation. $N$ number of viable cells in challenged sample; No number of viable cells in control; Error bars represent standard error for at least three independent experiments

was surprising since Gruber et al. (2004) recently proposed that Halobacterium sp. strain NRC-1 be classified as a strain of $H$. salinarium. The survival curve for Halobacterium sp. is identical to that reported for the desiccation-resistant Chroococcidiopsis species of cyanobacteria (Billi et al. 2000), indicating a similarity in adaptation among organisms inhabiting desiccating environments, whether it is desert or hypersaline.

Halobacterium sp. resistance to gamma ray was growth phase-dependent with increased sensitivity to irradiation in stationary phase $\left(\mathrm{OD}_{600 \mathrm{~nm}}>1.0\right)$ when compared to exponential growing cultures (early, mid, and late log phase) (Fig. 3). This is in contrast to the growth-phase dependence observed for most D. radiodurans isolates that are more resistant to gamma irradiation during stationary phase than exponential phase with the exception of isolate four that was more sensitive to both gamma and UV irradiation in stationary phase (Keller and Maxcy 1984; Makarova 2001). Increased resistance of $D$. radiodurans to gamma irradiation in stationary phase suggested that the DNA was more tightly packed in nongrowing cells and therefore less accessible to damage (Bala and Jain 1996). However, active removal of ROS, which are the major cause for DNA damage by gamma irradiation, might be more efficient in actively growing cells thereby explaining the increase in the survival of Halobacterium cells during exponential growth phase. 


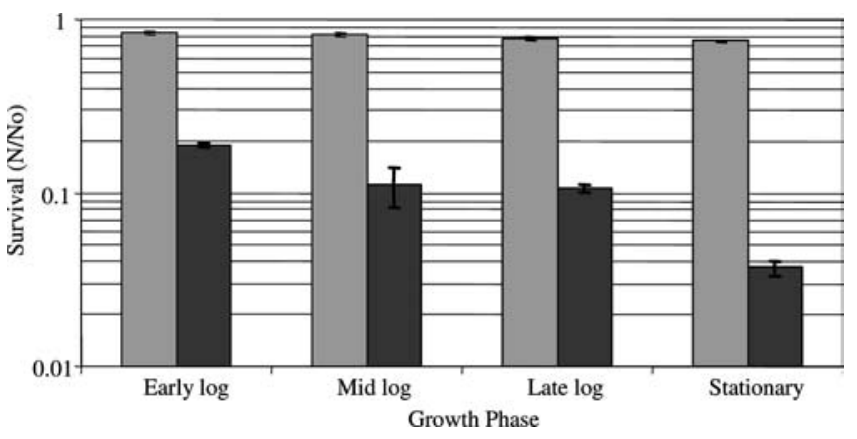

Fig. 3 Halobacterium sp. survival to $2.5 \mathrm{kGy}$ (light bars) and $5 \mathrm{kGy}$ (dark bars) of gamma irradiation at different growth stages. $\mathrm{OD}_{600 \mathrm{~nm}}$ values of $0.2,0.4,0.8$, and 1.0 were used to represent early $\log$, mid $\log$, late $\log$, and stationary phase, respectively. $N$ number of viable cells in challenged sample; No number of viable cells in control; Error bars represent standard error for three independent experiments

Halobacterium sp. repairs DNA DSBs produced by desiccation and gamma irradiation

It has previously been shown that $D$. radiodurans and the hyperthermophilic archaeon $P$. furiosus can efficiently repair DNA DSBs resulting from exposure to ionizing radiation (Moseley 1983; DiRuggiero et al. 1997). Here, we showed that both gamma irradiation and desiccation resulted in DNA DSBs in Halobacterium sp. and that those DNA breaks were repaired within several hours of incubation under optimal conditions (Fig. 4). In those experiments, DNA was liquid-extracted and the fluorescent smear under the genomic DNA band (at $\sim 23 \mathrm{~Kb}$ ) indicated additional DNA strand breaks due to exposure of the cells to ionizing radiation. Gammaray photons can cause direct damage to DNA, but the vast majority of the damage (over $80 \%$ ) is the indirect result of the radiolysis of water and the subsequent production of ROS including the biologically destructive hydroxyl radical (Riley 1994). Damages by ROS are limited by free radical scavengers such as catalase, peroxidase, and superoxide dismutase (Riley 1994) that are found encoded in the genome of Halobacterium sp. along with thioredoxin reductase, NADH oxidase, and DNA repair proteins encoding genes such as specific glycosylases and endonucleases ( $\mathrm{Ng}$ et al. 1997). The end result of damage by ionizing radiation are DNA DSBs that are typically repaired by RecA-mediated homologous recombination (HR) in D. radiodurans and in many Bacteria (Gutman et al. 1994; Daly et al. 1994; Minton and Daly 1995), although Ku-mediated nonhomologous end-joining has also been reported for several prokaryotes (Della et al. 2004). The genome of Halobacterium sp. does not encode a Ku-homolog but contain genes for several proteins involved in HR including $\operatorname{RadA}$, the RecA/Rad51 archaeal homolog (Komori et al. 2000a), an archaeal-type Holliday junction resolvase (Hjr), previously characterized in $P$. furiosus, (Komori et al. 200b), homologs of the eukaryotic MRX complex, Rad51/Mre11, also biochemically characterized in

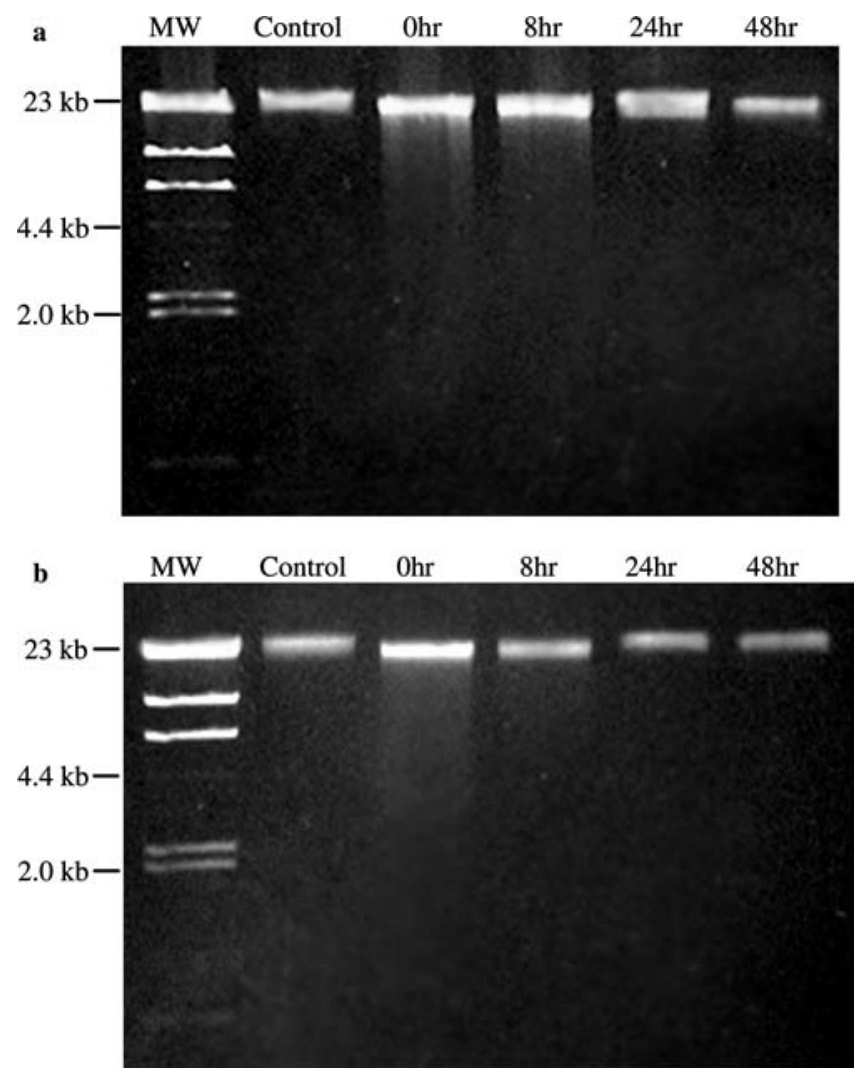

Fig. 4 Agarose gel electrophoresis of Halobacterium sp. DNA following a $144 \mathrm{~h}$ desiccation, and b ${ }^{60} \mathrm{Co}$ gamma irradiation at $7.5 \mathrm{kGy}$. Each lane contains DNA from approximately $2.2 \times 10^{8}$ cells. Lane 1, $50 \mathrm{~kb}$ ladder; lane 2, control non-treated; lane $3-6,0,8,24$ and $48 \mathrm{~h}$ of incubation at $42^{\circ} \mathrm{C}$, respectively, following treatment

P. furiosus (Hopfner et al. 2000), and a putative helicase, HerA (Constantinesco et al. 2004), suggesting that HR might be the major pathway for DSBs repair in Halobacterium $s p$.

We further investigated the molecular mechanisms for DSB repair in Halobacterium sp. by testing the potential for acquired radiation and desiccation tolerance following low-level gamma irradiation. Inducible stress systems are present in Bacteria and Eukarya (Crawford and Davies 1994, Ulsh et al. 2004) and acquired thermoresistance was reported for thermophilic archaea following exposure to nonlethal heat shock (Holden and Baross 1993; Trent et al. 1994). We did not find increased survival of Halobacterium sp. to desiccation exposure or ionizing irradiation when the cells were first exposed to a nonlethal dose of gamma irradiation (Fig. 5). In the case of desiccation, preexposure to $0.5 \mathrm{kGy}$ of gamma ray resulted in a slight decrease in survival after desiccation, when compared to desiccation without preexposure (Fig. 5). The absence of an inducible system for the repair of gamma-induced DNA damage is consistent with the lack of DNA repair inducible pathways in Halobacterium sp. cells after UV irradiation, with the exception of a novel mismatch repair pathway (Baliga et al. 2004). No coordinated 


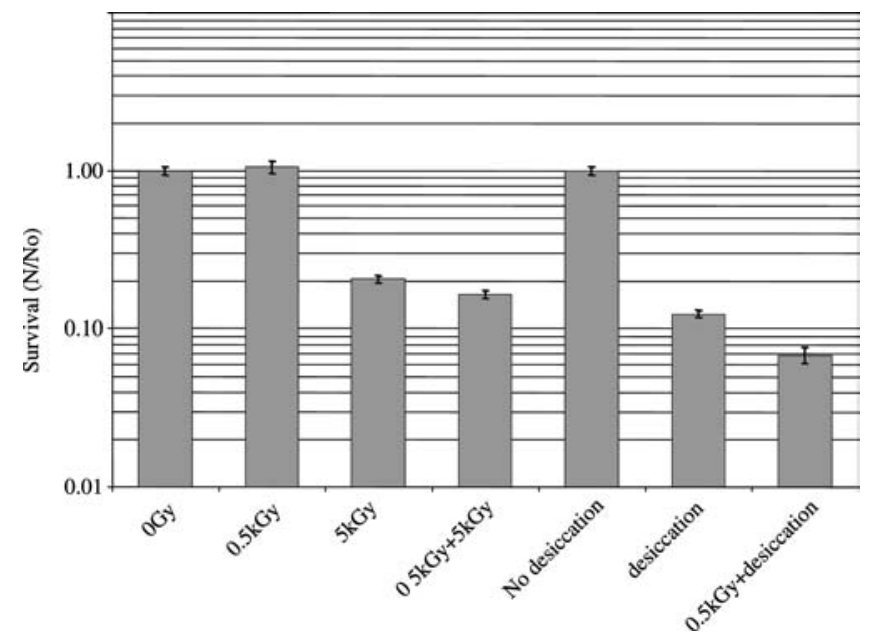

Fig. 5 Halobacterium sp. survival after irradiation at a non-lethal dose $(0.5 \mathrm{kGy})$ prior to either irradiation at $5 \mathrm{kGy}$ or desiccation for 12 days. $N$ number of viable cells in challenged sample; No number of viable cells in control; Error bars represent standard deviation for six replicates

DNA repair response, similar to the bacterial SOS response to DNA damage was found in Halobacterium sp. following UV irradiation (Baliga et al. 2004), or in both Halobacterium sp. and $P$. furiosus following ionizing radiation (DiRuggiero, unpublished). Furthermore, Pyrococcus abyssi was also found to lack an inducible response for DNA repair following gamma irradiation (Gerard et al. 2001).

Resistance to high levels of gamma irradiation is unexpected in terrestrial organisms since there is no large natural source of gamma-ray on Earth. It has been proposed that $D$. radiodurans adaptation to desiccation accounts for its resistance to ionizing radiation due to the fact that the same types of DNA lesions, DSBs, are incurred by exposure to either condition (Mattimore and Battista 1996). Chroococcidiopsis strains from both desert and hypersaline environments were also found to be resistant to ionizing radiation (Billi et al. 2000), suggesting in turn that Halobacterium's adaptation to low water pressure resulting from water evaporation and high salt concentration in hypersaline pools, also accounts for its survival to high levels of gamma irradiation.

Halobacterium sp. DNA is protected against DNA double-stranded breaks

A mutant strain of Halobacterium sp. constructed by gene deletion from a $\Delta u r a 3$ background strain and lacking all four rhodopsin pigments $(\triangle \mathrm{Pho} 81)$, and a colorless random EMS mutant (BA3) were examined for survival after gamma irradiation. Neither mutant exhibited a loss of survival at lower doses of gamma irradiation $(2.5 \mathrm{kGy})$, whereas a modest decrease in survival was observed in both mutants at the higher dose of $5 \mathrm{kGy}$, when compared to their respective control

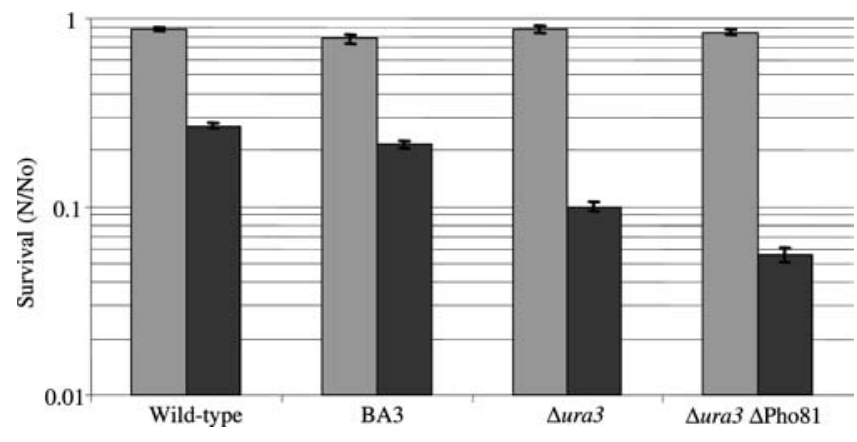

Fig. 6 Survival of $\Delta \mathrm{Pho} 81$ (deletion of four rhodopsin pigments), BA3 (EMS-generated colorless mutant), $\Delta u r a 3$ deletion background strain and Halobacterium sp. wild type strain to 2.5 (light bars) and $5 \mathrm{kGy}$ (dark bars) of ${ }^{60} \mathrm{Co}$ gamma irradiation. $N$ number of viable cells in challenged sample; No number of viable cells in control; Error bars represent standard error for three independent experiments

strains (Fig. 6). Protection by red membrane protein pigments has previously been demonstrated to mitigate the damaging effects of UV and gamma irradiation in H. salinarium (Shahmohammadi et al. 1998) and D. radiodurans (Carbonneau et al. 1989). In previous studies, exposing Halobacterium sp. mutant strain BA3 to $200 \mathrm{~J} / \mathrm{m}^{2}$ of UV-C $(254 \mathrm{~nm})$ irradiation resulted in a two-fold decrease in survival when cells were allowed to recover in the dark, compared to wild-type cells, also suggesting pigment protection against photooxidative damage (DiRuggiero and Kottemann, unpublished data). In both $H$. salinarium and $D$. radiodurans a $\mathrm{C}_{50^{-}}$ carotenoid, bacteriorubrin, was identified as being particularly effective in scavenging hydroxyl radicals thereby reducing the damage to nucleic acids. It must be noted that since the BA3 mutant was derived from EMS mutagenesis, and was not subjected to any further genetic characterization, the decreases in survival after both UV (dark recovery) and gamma irradiation could be the result of another non-observable mutation. Overall, at low doses of ${ }^{60} \mathrm{Co}$ gamma irradiation DNA repair mechanisms alone are adequate, but at higher doses repair mechanisms may get overwhelmed and the free radical scavenging activities of $\mathrm{C}_{50}$-carotenoid pigments reducing the DNA damage caused by ionizing radiation becomes apparent.

The protective effects of salts were investigated by comparing Halobacterium sp. resistance to gamma to that of E. coli grown in $0.1 \mathrm{M} \mathrm{NaCl}$, compared to $4.3 \mathrm{M}$ $\mathrm{NaCl}$ for Halobacterium sp. Chromosomal fragmentation in Halobacterium sp. after gamma irradiation at 2.5, 5 , and $7.5 \mathrm{kGy}$ was far less extensive at the same dosage than that observed for E. coli (Fig. 7). E. coli survival after gamma irradiation was roughly $1 \%$ at $2.5 \mathrm{kGy}$, $0.1 \%$ at $5 \mathrm{kGy}$, and $0.001 \%$ at $7.5 \mathrm{kGy}$ while Halobacterium sp. cultures proved considerably more viable with $85 \%$ survival at $2.5 \mathrm{kGy}, 28 \%$ at $5 \mathrm{kGy}$, and $0.4 \%$ at $7.5 \mathrm{kGy}$ (data not shown). Densitometry analysis of the agarose gel showed a large increase in fluorescence intensity corresponding to further DNA fragmentation 
Fig. 7 a Agarose gel

electrophoresis of

Halobacterium sp. and E. coli

DNA following exposure to 0 , $2.5,5$, and $7.5 \mathrm{kGy}$ of ${ }^{60} \mathrm{Co}$ gamma-ray. Each lane contains DNA from approximately $2.2 \times 10^{8}$ cells. Lane $1,50 \mathrm{~kb}$ ladder; lanes $2-5$,

Halobacterium sp.; lanes 6-9, E. coli. b Fluorescence intensity of Halobacterium sp. (light bars) and E. coli (dark bars) DNA gel electrophoresis from a using ImageQuaNT5.0. The $0 \mathrm{kGy}$ samples (Halobacterium sp. and E. coli) were used as background and subtracted from the respective samples

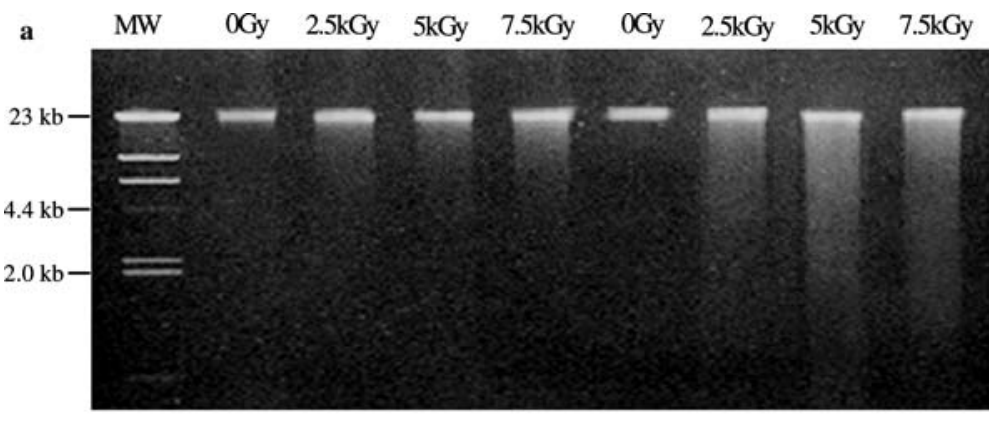

b

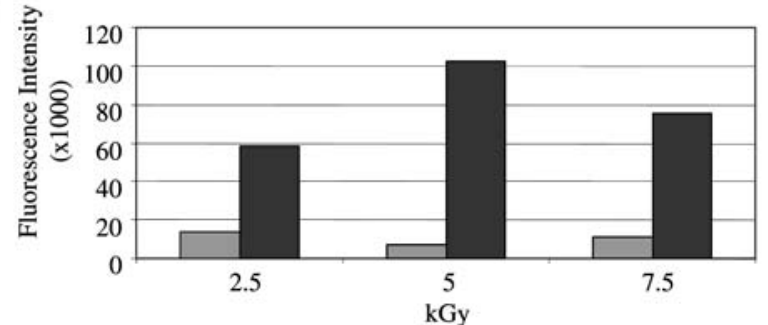

in E. coli as the dose of gamma irradiation increased while in Halobacterium sp. DNA fragmentation remained low (Fig. 7).

Intracellular salts such as $\mathrm{KCl}$ have previously been found to mitigate the effects of oxidative free radicals produced by the radiolysis of water by ionizing radiation in an in vitro study using plasmid DNA (Shahmohammadi et al. 1998). Chloride anions react with hydroxyl radicals and then with other chloride anions to produce chloride radicals, which are far less reactive than hydroxyl radicals. In hyperthermophilic species, high intracellular $\mathrm{KCl}$ was shown to reduce DNA cleavage at apurinic sites and to inhibit depurination (Marguet and Forterre 1998). A different protection strategy has been proposed for D. radiodurans. The accumulation of $\mathrm{Mn}$ (II) resulting in high intracellular $\mathrm{Mn}: \mathrm{Fe}$ ratios were found to be important in radioresistance not only for $D$. radiodurans, but also for several other extremely radiation resistant bacterial species (Daly et al. 2004). Mn is a cofactor for the free radical scavenging Mn-dependant superoxide dismutase, whereas Fe participates in the Fenton reaction resulting in the formation of hydroxyl radicals from $\mathrm{H}_{2} \mathrm{O}_{2}$. Like other extremely radioresistant prokaryotes, Halobacterium $\mathrm{sp}$. does not sporulate but, unlike D. radiodurans, $\mathrm{Fe}$ is a requirement for cell growth (Hubmacher et al. 2002). Thus the presence of salts rather than $\mathrm{Mn}$ accumulation is a vital factor in gamma radiation protection in Halobacterium sp., although like $D$. radiodurans the exact mechanism of protection is unknown.

\section{Conclusions}

We have shown here the extreme resistance of Halobacterium sp. to up to 20 days of desiccation, high vacuum and ionizing radiation $\left(\mathrm{D}_{10}=5 \mathrm{kGy}\right)$. No acquired tolerance to desiccation or gamma irradiation was observed. Chromosomal fragmentation induced by $144 \mathrm{~h}$ of desiccation or $7.5 \mathrm{kGy}$ of gamma irradiation was repaired within hours. Similarly to D. radiodurans, Halobacterium sp. adaptation to desiccation secondarily allows for resistance to gamma irradiation as both conditions result in the formation of DSBs. Our data suggest that, in Halobacterium sp., bacteriorubrin and intracellular salts such as $\mathrm{KCl}$ aid in restricting DNA DSB formation resulting from exposure to desiccation and high doses of gamma irradiation. Survival within brine inclusions provides an extra layer of protection by which Halobacterium sp. cells can withstand both desiccation and high vacuum. Efficient DNA repair systems (likely HR) increase cell survival after gammaray exposure or desiccation. The mechanisms of radiotolerance with emphasis on DNA repair systems in Archaea require further study, for which Halobacterium sp. strain NRC-1 provides an excellent model system.

Acknowledgements This work was supported by grants from NASA (\#NCC9147), and the HFSP (\#RG522002). We would like to thank Vince Adams for his technical assistance irradiating the cells and Marvin Swartz for high vacuum exposure.

\section{References}

Bala M, Jain V (1996) 2-DG induced modulation of chromosomal DNA profile, cell survival, mutagenesis and gene conversion in X-irradiated yeast. Indian J Exp Biol 34(1):18-26

Baliga NS, Bjork SJ, Bonneau R, Pan M, Iloanusi C, Kottemann MC, Hood L, DiRuggiero J (2004) Systems level insights into the stress response to UV radiation in the halophilic archaeon Halobacterium NRC -1. Genome Res 14(6):1025-1035 [Epub 2004 May 12]

Battista JR, Earl AM, Park MJ (1999) Why is Deinococcus radiodurans so resistant to ionizing radiation? Trends Microbiol $7: 362-365$ 
Billi D, Friedmann EI, Hofer KG, Caiola MG, Ocampo-Friedmann R (2000) Ionizing-radiation resistance in the desiccationtolerant Cyanobacterium Chroococcidiopsis. Appl Environ Microbiol 66(4):1489-1492

Blaisdell JO, Wallace SS (2001) Abortive base-excision repair of radiation-induced clustered DNA lesions in Escherichia coli. PNAS USA 98(13):7426-7430

Carbonneau MA, Melin AM, Perromat A, Clerc M (1989) The action of free radicals on Deinococcus radiodurans carotenoids. Arch Biochem Biophys 275(1):244-251

Clavero MRS, Monk JD, Beuchat LR, Doyle MP, Brackett RE (1994) Inactivation of Escherichia coli 0157:H7, Salmonellae, and Campylobacter jejuni in raw ground beef by gamma irradiation. Appl Environ Microbiol 60(6):2069-2075

Constantinesco F, Forterre P, Koonin E, Aravind L, Elie C (2004) A bipolar DNA helicase gene, her A, clusters with rad50, mre11 and nur $A$ genes in thermophilic archaea. Nucleic Acids Res 32:1439-1447

Crawford DR, Davies KJ (1994) Adaptive response and oxidative stress. Environ Health Perspect 102(Suppl)10:25-28

Daly MJ, Ouyang L, Fuchs P, Minton KW (1994) In vivo damage and recA-dependent repair of plasmid and chromosomal DNA in the radiation-resistant bacterium Deinococcus radiodurans. J Bacteriol 176(12):3508-3517

Daly MJ, Gaidamakova EK, Matrosova VY, Vasilenko A, Zhai M, Venkateswaran A, Hess M, Omelchenko MV, Kostandarithes HM, Makarova KS, Wackett LP, Fredrickson JK, Ghosal D (2004) Sep 30 Accumulation of $\mathrm{Mn}(\mathrm{II})$ in Deinococcus radiodurans facilitates gamma-radiation resistance. Science [Epub ahead of print]

Della M, Palmbos PL, Tseng H-M, Tonkin LM, Daley JM, Topper LM, Pitcher RS, Tomkinson AE, Wilson TE, Doherty AJ (2004) Mycobacterial $\mathrm{Ku}$ and ligase proteins constitute a twocomponent NHEJ repair machine. Science 360:683-685

Dianov GL, O'Neill P, Goodhead DT (2001) Securing genome stability by orchestrating DNA repair: removal of radiationinduced clustered lesions in DNA. BioEssays 23:745-749

DiRuggiero J, Santangelo N, Nackerdien Z, Ravel J, Robb FT (1997) Repair of extensive ionizing-radiation DNA damage at $95^{\circ} \mathrm{C}$ in the hyperthermophilic archaeon Pyrococcus furiosus. J Bacteriol 179:4643-4645

DiRuggiero J, Brown JR, Bogert AP, Robb FT (1999) DNA repair systems in Archaea: mementos from the last universal common ancestor? J Mol Evol 49:474-484

Fish SA, Shepherd TJ, McGenity TJ, Grant WD (2002) Recovery of $16 \mathrm{~S}$ ribosomal RNA gene fragments from ancient halite. Nature 417(6887):432-436

Gerard E, Jolivet E, Prieur D, Forterre P (2001) DNA protection mechanisms are not involved in the radioresistance of the hyperthermophilic archaea Pyrococcus abyssi and P. furiosus. Mol Genet Genomics 266(1):72-78

van Gerwen SJ, Rombouts FM, van't Riet K, Zwietering MH (1999) A data analysis of the irradiation parameter D10 for bacteria and spores under various conditions. J Food Prot 62(9): 1024-1032

Gruber C, Legat A, Pfaffenhuemer M, Radax C, Weidler G, HansJürgen B Helga S-L (2004) Halobacterium noricense sp. nov., an archaeal isolate from a bore core of an alpine Permian salt deposit, classification of Halobacterium sp. NRC-1 as a strain of $H$. salinarum and emended description of $H$. salinarum. Extremophiles [E-pub 30 July 2004]

Gutman PD, Carroll JD, Masters CI, Minton KW (1994) Sequencing, targeted mutagenesis and expression of a $r e c A$ gene required for the extreme radioresistance of Deinococcus radiodurans. Gene 141:31-37

Holden JF, Baross JA (1993) Enhanced thermotolerance and temperature-induced changes in protein composition in the hyperthermophilic archaeon ES4. J Bacteriol 175:2839-2843

Hopfner KP, Karcher A, Shin D, Fairley C, Tainer JA, Carney JP (2000) Mre11 and Rad50 from Pyrococcus furiosus: cloning and biochemical characterization reveal an evolutionarily conserved multiprotein machine. J Bacteriol 182(21):6036-6041
Hubmacher D, Matzanke BF, Anemuller S (2002) Investigations of iron uptake in Halobacterium salinarum. Biochem Soc Trans 4:710-712

Jolivet E, L'Haridon S, Corre E, Forterre P, Prieur D (2003) Thermococcus gammatolerans sp. nov., a hyperthermophilic archaeon from a deep-sea hydrothermal vent that resists ionizing radiation. Int J Syst Evol Microbiol 53(3):847-851

Jolivet E, Corre E, L'Haridon S, Forterre P, Prieur D (2004) Thermococcus marinus sp. nov. and Thermococcus radiotolerans sp. nov., two hyperthermophilic archaea from deep-sea hydrothermal vents that resist ionizing radiation. Extremophiles 8(3):219-227. [Epub 2004 Feb 27]

Keller LC, Maxcy RB (1984) Effect of physiological age on radiation resistance of some bacteria that are highly radiation resistant. Appl Environ Microbiol 47(5):915-918

Koike J, Oshima T, Koike KA, Taguchi H, Tanaka R, Nishimura K, Miyaji M (1992) Survival rates of some terrestrial microorganisms under high conditions. Adv Space Res 12(4):271-274

Komori K, Miyata T, DiRuggiero J, Holley-Shanks R, Hayashi I, Cann IK, Mayanagi K, Shinagawa H, Ishino Y (2000a) Both RadA and RadB are involved in homologous recombination in Pyrococcus furiosus. J Biol Chem 275(43):33782-33790

Komori K, Sakae S, Fujikane R, Morikawa K, Shinagawa H, Ishino Y (2000b) Biochemical characterization of the $\mathrm{Hjc}$ Holliday junction resolvase of Pyrococcus furiosus. Nucleic Acids Res 28(22):4544-4551

Lanyi JK (1974) Salt-dependent properties of proteins from extremely halophilic bacteria. Bacteriol. Rev 38:272-290

Makarova KS, Aravind L, Wolf YI, Tatusov RL, Minton KW, Koonin EV, Daly MJ (2001) Genome of the extremely radiation-resistant bacterium Deinococcus radiodurans viewed from the perspective of comparative genomics. Microbiol Mol Biol Rev 65(1):44-79

Mancinelli RL, White MR, Rothschild LJ (1998) Biopan-survival I: Exposure of the Osmophiles Synechococcus Sp. (Nageli) and Haloarcula $\mathrm{Sp}$. to the space environment. Adv Space Res 22:327

Marguet E, Forterre P (1998) Protection of DNA by salts against thermodegradation at temperatures typical for hyperthermophiles. Extremophiles 2(2):115-122

Martin EL, Reinhardt RL, Baum LL, Becker MR, Shaffer JJ, Kokjohn TA (2000) The effects of ultraviolet radiation on the moderate halophile Halomonas elongata and the extreme halophile Halobacterium salinarum. Can J Microbiol 46(2):180-187

Mattimore V, Battista JR (1996) Radioresistance of Deinococcus radiodurans: functions necessary to survive ionizing radiation are also necessary to survive prolonged desiccation. J Bacteriol 178(3):633-637

McCready S (1996) The repair of ultraviolet light-induced DNA damage in the halophilic archaebacteria, Halobacterium cutirubrum, Halobacterium halobium and Haloferax volcanii. Mutat Res 364(1):25-32

McGenity TJ, Gemmell RT, Grant WD, Stan-Lotter H (2000) Origins of halophilic microorganisms in ancient salt deposits. Environ Microbiol 2(3):243-50

Minton KW, Daly MJ (1995) A model for repair of radiationinduced DNA double-strand breaks in the extreme radiophile Deinococcus radiodurans. BioEssays 17(5):457-464

Moseley BEB (1983) Photobiology and radiobiology of Micrococcus (Deinococcus) radiodurans. Photochem Photobiol Rev 7:223-275

Ng WL, Yang CF, Halladay JT, Arora P, DasSarma S (1995) Protocol 25: isolation of genomic and plasmid DNAs from Halobacterium halobium. In: Robb FT, Place AR, Sowers KR, Schreier HJ, DasSarma S, Fleischmann EM (eds) Archaea: a laboratory manual. Cold Spring Harbor Laboratory Press, Newyork pp 179-180

Ng WV, Kennedy SP, Mahairas GG, Berquist B, Pan M, Shukla HD, Lasky SR, Baliga N, Thorsson V, Sbrogna J, Swartzell S, Weir D, Gall J, Dahl TA, Welti R, Goo YA, Leithauser B, Keller K, Cruz R, Danson MJ, Hough DW, Maddocks DG, Jablonski PE, Krebs MP, Angevine CM, Dale H, Isenbarger TA, Peck RF, Pohlschrod M, Spudich JL, Jung KH, Alam M, 
Freitas T, Hou S, Daniels CJ, Dennis PP, Omar AD, Ebhardt H, Lowe TM, Liang P, Riley M, Hood L, DasSarma S (1997) Genome sequence of Halobacterium species NRC-1. PNAS USA 22:12176-12181

Nicholson WL, Munakata N, Horneck G, Melosh HJ, Setlow P (2000) Resistance of Bacillus endospores to extreme terrestrial and extraterrestrial environments. Microbiol Mol Biol Rev 64(3):548-572

Peck RF, DasSarma S, Krebs MP (2000) Homologous gene knockout in the archaeon Halobacterium salinarium with ura3 as a counterselectable marker. Mol Micro 35(3):667-676

Potts M (1994) Desiccation tolerance of Prokaryotes. Microbiol Rev 58(4):755-805

Rieder R, Gellert R, Anderson RC, Bruckner J, Clark BC, Dreibus G, Economou T, Klingelhofer G, Lugmair GW, Ming DW, Squyres SW, d'Uston C, Wanke H, Yen A, Zipfel J (2004) Chemistry of rocks and soils at Meridiani Planum from the alpha particle X-ray spectrometer. Science 306(5702):1746-1749

Riley PA (1994) Free radicals in biology: oxidative stress and the effects of ionizing radiation. Int $\mathbf{J}$ Radiat Biol 65(1):27-33

Saffary R, Nandakumar R, Spencer D, Robb FT, Davila JM, Swartz M, Ofman L, Thomas RJ, DiRuggiero J (2002)
Microbial survival of space vacuum and extreme ultraviolet irradiation: strain isolation and analysis during a rocket flight. FEMS Microbiol Lett 215(1):163-168

Salin MN, Brown-Peterson NJ (1993) Dealing with active oxygen intermediates: a halophilic perspective. Experientia 49:523529

Shahmohammadi HR, Asgarani E, Terato H, Saito T, Ohyama Y, Gekko K, Yamamoto O, Ide H (1998) Protective roles of bacterioruberin and intracellular KCL resistance of Halobacterium salinarium against DNA-damaging agents. J Radiat Res 39:251-262

Trent JD, Gabrielsen M, Jensen B, Neuhard J, Olsen J (1994) Acquired thermotolerance and heat shock proteins in thermophiles from the three phylogenetic domains. J Bacteriol 176:6148-6152

Ulsh BA, Miller SM, Mallory FF, Mitchel RE, Morrison DP, Boreham DR (2004) Cytogenetic dose-response and adaptive response in cells of ungulate species exposed to ionizing radiation. J Environ Radioact 74(1-3):73-81

Vreeland RH, Rosenzweig WD (2002) The question of uniqueness of ancient bacteria. J Ind Microbiol Biotechnol 28(1):32-41 